\title{
Rural Electrification Program in Indonesia: Comparing SEHEN and SHS Program ${ }^{\underline{2}}$
}

\author{
Maxensius Tri Sambodoa,* \\ a Indonesian Institute of Sciences (LIPI)
}

\begin{abstract}
In 2014 , the Indonesian government had targets to obtain $80 \%$ of electrification ratio and $98.9 \%$ of rural electrification ratio. Extending the grid and off-grid connection has been done to obtain the targets. This paper aims to compare two main programs on rural electrification namely Super Extra Energy Saving (Super Ekstra Hemat Energi, SEHEN) that belongs to the PLN (state-owned company in electricity) and the Solar Home System (SHS) that is financed by the Ministry of Energy and Mineral Resources (MEMR). Indonesia started the rural electrification program in the late 1950s, but how to provide electricity in a sustainable ways both organizationally and institutionally still becomes a big challenge. The experiences from East Nusa Tenggara provinces showed that both SEHEN and SHS can instantly improve electrification ratio, but government needs to synchronize the technical, administrative, and financial aspect from the two programs. Without any improvements in designing the program, we argue that the existing program is not sustainable. Keywords: Electrification Ratio; Rural Electrification; Sustainability
\end{abstract}

\begin{abstract}
Abstrak
Tahun 2014, Pemerintah Indonesia menetapkan target pencapaian rasio elektrifikasi sebesar $80 \%$ dan rasio elektifikasi perdesaan sebesar $98.9 \%$. Perpanjangan jaringan grid dan off-grid telah dilakukan sepagai upaya pencapaian target. Tulisan ini bertujuan membandingkan dua program elktifikasi perdesaan yang utama, yaitu Super Ekstra Hemat Energi (SEHEN) yang dimiliki PLN (Badan Usaha Milik Negara di bidang kelistrikan) dan Solar Home System (SHS) yang didanai Kementerian Energi dan Sumber Daya Mineral. Indonesia telah memulai program elektrifikasi perdesaan sejak akhir 1950an, namun masih menghadapi tantangan dalam menemukan cara elektrifikasi yang berkesinambungan secara organisasional maupun institusional. Pengalaman dari Provinsi Nusa Tenggara Timur menunjukkan bahwa SEHEN maupun SHS dapat meningkatkan rasio elektrifikasi secara signifikan, namun pemerintah masih harus menyelaraskan aspek teknis, administratif, dan keuangan dari kedua program. Tanpa pembenahan dari sisi rancangan, kami berpendapat bahwa program yang telah ada tidak ada bertahan.
\end{abstract}

Kata kunci: Rasio Elektrifikasi; Listrik Perdesaan; Keberlanjutan

JEL classifications: O10; Q40

\section{Introduction}

This paper is part of a research project with the title 'Model dan Strategi Pengembangan Sektor Ketenagalistrikan di Daerah Dalam Upaya Pengentasan Kemiskinan [Models and Strategies in Developing Electricity Sector in Regions for Poverty Alleviation]' Year 2013-2014. Author is grateful to LIPI who provided the competitive research grant under the Subtheme Critical and Strategic Social Issues (CSSI) program. Author is grateful for valuable comments from anonymous reviewer.

* Researcher at Economic Research Center, Indonesian Institute of Sciences (LIPI) and Visiting Fellow at Institute of Southeast Asian Studies (ISEAS).
In 2013, the ratio of electrification was about $78.06 \%$ (PT PLN 2013) and the government had determined that in 2014, the electrification ratio needs to reach $80 \%$. During the Susilo

Corresponding Address: Widya Graha LIPI, Jend. Gatot Subroto Street No. 10, IV \& V Floor, Jakarta Selatan 12710 Indonesia. Phone: +62-21-5207120, Fax.: +62-215262139. E-mail: smaxensius@yahoo.com; maxensius.tri. sambodo@lipi.go.id; maxensius_sambodo@iseas.edu.sg. 
Bambang Yudhoyono presidency, PLN (the stateowned electricity company) had a Vision 75-100 or in 2020 (on the 75th national independence day, electrification ratio reaches $100 \%$ ). Even, the postSusilo Bambang Yudhoyono administrative aimed to obtain electrification ratio by $100 \%$ in 2019 (one year sooner). However, it is a huge variation in terms of electrification ratio accross the provinces. For example, electrification ratio in DKI Jakarta province reached $95.39 \%$ while in Papua and East Nusa Tenggara Province, it was about $27.93 \%$ and $48.3 \%$ respectively (PT PLN 2013). One of the programs that can improve electrication ratio especially in rural areas is the rural electrification program. In 2003, the Indonesian government launched the Village Self-Sufficiency on Energy [Desa Mandiri Energi/DME]. The DME is based on two pillars: non-oil such as micro hydro, wind power, photo voltaic (PV), and biomass; and non-fossil oil such as biofuel and bioethanol. Based on the Master Plan of Electricity Development 2010-2014 that was issued by the Minister of Energy and Mineral Resources (MEMR) in December 2009, government defined rural electrification as the share of total village with electricity access to total number of village. The master plan shows planning on additional capacity of rural electrification for 33 provinces. The master plan also indicates that government will provide subsidies to improve rural electrification ratio.

The existing condition of rural electrification ratio indicates that most of the provinces have the ratio of above $87 \%$, even some provinces such as DKI Jakarta, Central Java, DI Yogyakarta, North Sulawesi, South Sulawesi, West Nusa Tenggara have about $100 \%$ (except in Papua and Papua Barat that was about $30 \%$ ). The Indonesian government has determined that the rural electrification ratio in 2014 will reach $98.9 \%$. By considering the definition of electrification ratio and rural electrification ratio, we can conclude that there are still many households in rural level that do not have access on electricity. Most of them could be in the remote area that are located very far away from the national power grid. Furthermore, having access on electricitiy does not mean customers have high quality of power supply. SAIDI and SAIFI that measure reliability of power supply are still high in some provinces ${ }^{1}$. For example, in West Java and Banten

${ }^{1}$ SAIDI = System Average Interruption Duration Index and the level of SAIDI and SAIFI was about 1.71 hours per customer and 2.8 times per customer respectively, while in Papua it was about 7.63 hours per customer and 9.51 times per customer respectively (PT PLN 2012a). This indicates that in Papua region the quality of power supply has been lower than in West Java and Banten area.

This paper aims to evaluate the current development of rural electrification programs in Indonesia. We focused on rural electrification program that have been implemented by two agencies such as PLN under the name of Super Extra Energy Saving (Super Ekstra Hemat Energi/SEHEN) and the Ministry of Energy and Mineral Resources (MEMR) under the name of solar home system (SHS). We also analyzed experiences from East Nusa Tenggara (Nusa Tenggara Timur/NTT) Province. We divided the analysis into five sections. After the introduction, we briefly reviewed the main studies that discuss rural electrification programs in the past. Next, we discussed the method of analysis. Section four, analyzed the existing rural electrification programs that have been done by PLN, central and local government. In this section, we also discussed the lessons learned from SEHEN and SHS program in NTT province. Finally, section five consists of conclusion and recommendation.

\section{Literature Review}

\subsection{Rural Electrification Program in Brief}

Rural electrification (RE) program was initiated in Indonesia by the late fifties and the program was based on small isolated diesel schemes (McCawley 1978). McCawley (1978) said that the main reason for RE is the hope that productivity in agriculture and rural industries will improve. Munasinghe (1988) pointed out two objectives of rural electrification program such as promoting economic growth and creating equity.

$\overline{\mathrm{SAIFI}}=$ System Average Interruption Frequency Index. The difference between the two indicators is that SAIDI calculate duration of customers who are blackout, while SAIFI only consider the number of customers who are blackout. Thus, the lower SAIDI and SAIFI is the better quality of power supply. 


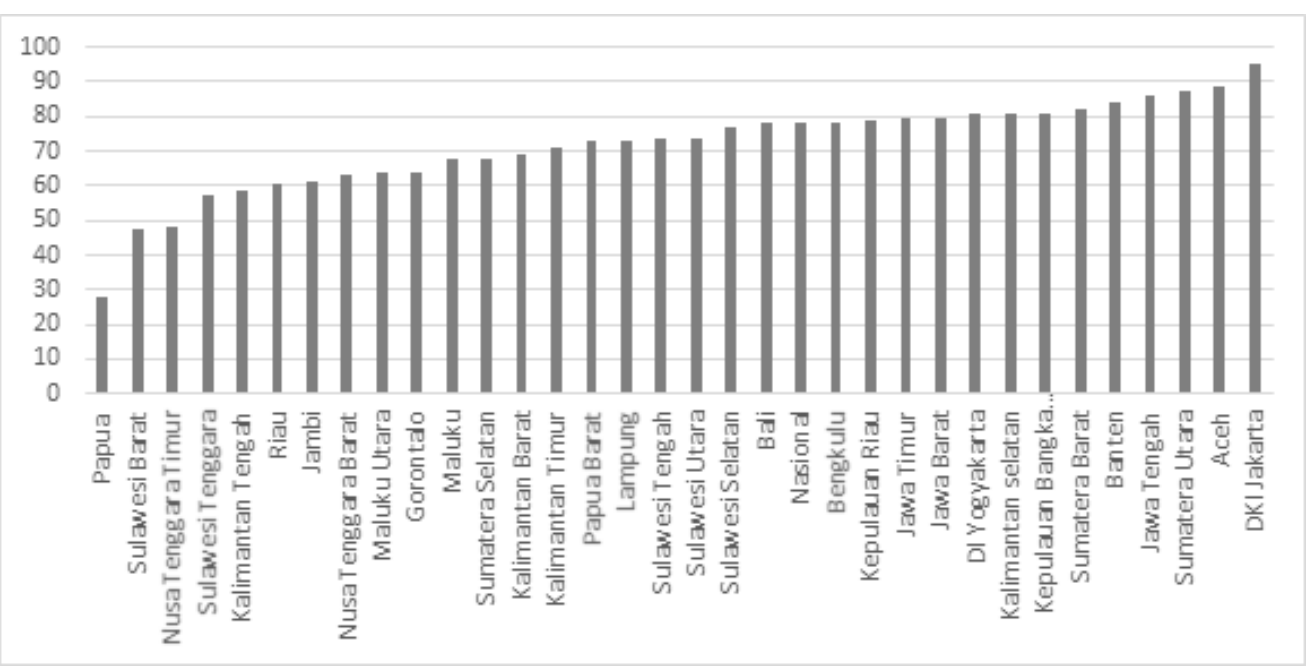

Figure 1: Electrification Ratio in 2013 (in Percentage)

President Soekarno during his speech to celebrate the Gas and Electricity Day, in 1960, said that in 1985 all of Indonesia would have been electrified. The director general of Department of Manpower, Transmigration, and Cooperative in 1976 also said that in 2000 , Indonesia aimed to electrify the majority of its 60,000 villages. In 1978, for the first time President Soeharto mentioned electrification program in the Indonesia's Broad Guidelines of State Policy (Garis-Garis Besar Haluan Negara/GBHN). However, Mohsin (2014) argued that during the new order regime, the rural electrification program or well-known as Listrik Masuk Desa had two functions. First, it was a tool to improve economic conditions of villages. Second, it was a political instrument for the GOLKAR party to secure votes (votebuying strategy) from rural people in the general elections.

Increasing electrification ratio always becomes challenging task because Indonesia has many islands and many communities are isolated from one another. However, providing access to modern energy sources can enhance Indonesia to obtain the Millennium Development Goals (MDGs). Winkler et al. (2011) said that the improvement on electricity access and affordability are important. This indicates that government needs to help the poor to have better access in energy. Kanagawa and Nakata (2008) have shown that energy relates with poverty indicators such as health, education, income, and environment. Kanagawa and Nakata (2008) indicated that access on electricity depends on infrastructure conditions, capacity of supply, government policy and international cooperation.

Access on electricity also needs to consider a sufficiency dimension. There are incremental levels of electricity consumption such as basic needs, productive uses and modern society needs. AGECC (2010) suggested that at the basic human needs, there is a minimum threshold of electricity consumption or it is about $50-100 \mathrm{kWh}$ person per year (see Table 1). At the minimum level, electricity cannot be extended for productive uses, but at this level electricity can be used for lighting purpose. Having access on lighting can extent activities in the night and some people that used kerosene lamp can reduce kerosene consumption. However, for productive use, the level of electricity consumption is between $100 \mathrm{kWh}$ and 2,000 kWh per person per year. It seems that the level of electricity consumption tends to increase as the income increases. However, because the majority of power generating comes from non-renewable sources, it is necessary to conserve the electricity used.

Government has shared the willingness to promote rural electrification ratio, but how to provide it in a sustainable way both organizationally and institutionally still becomes a big challenge. McCawley (1978) pointed out six main elements of rural electrification problems: technical difficulties, quality of service, administration, level of demand, high costs, and the financing programs. The summary 
Table 1: Incremental Levels of Access to Energy Services

\begin{tabular}{|c|c|c|}
\hline $\begin{array}{l}\text { Level } 1 \\
\text { Basic Human Needs }\end{array}$ & $\begin{array}{l}\text { Level } 2 \\
\text { Productive Uses }\end{array}$ & $\begin{array}{l}\text { Level } 3 \\
\text { Modern Society Needs }\end{array}$ \\
\hline \multirow{3}{*}{$\begin{array}{l}\text { Electricity for lighting, health, education, } \\
\text { communication and community services } \\
\text { (50-100 kWh per person per year). } \\
\text { Modern fuels and technologies for cook- } \\
\text { ing and heating ( } 50-100 \text { kgoe of modern } \\
\text { fuel or improved biomass cook stove). }\end{array}$} & $\begin{array}{l}\text { Electricity, modern fuels and other en- } \\
\text { ergy services to improve productivity e.g. }\end{array}$ & \multirow[t]{3}{*}{$\begin{array}{l}\text { Modern energy services for many more } \\
\text { domestic appliances, increased require- } \\
\text { ments for cooling and heating (space and } \\
\text { water) private transportation (electricity } \\
\text { usage is around } 2,000 \text { kwh per person } \\
\text { per year). }\end{array}$} \\
\hline & $\begin{array}{l}\text { - Agriculture: water pumping for irriga- } \\
\text { tion, fertilizer, mechanized tilling }\end{array}$ & \\
\hline & $\begin{array}{l}\text { - Commercial: agricultural processing } \\
\text { cottage industry } \\
\text { - Transport: fuel }\end{array}$ & \\
\hline
\end{tabular}

Source: AGECC (2010)

of McCawley's arguments is as follows. Technical difficulties attach to ability for operating and maintenance. This includes quality of technical staff. Low quality of service is mainly due to low electricity tariff and technical difficulties. Administration indicates that there is a lack in specialist institutions with considerable expertise in rural electrification schemes. The level of substantial effective demand needs to be assessed. The average price of $\mathrm{kWh}$, ability of customers to make the capital outlays associated with consumption of electricity, prospect of economic growth, and quality of services influence the electricity demand. Regarding the cost, most of unit cost (tariff per kWh) delivered to consumers in rural areas is high, both relative to the cost of urban areas, and relative to consumers' expectation. This is due to technical inefficiencies in transmissions and distribution, administrative difficulties, underutilization of transmission and distribution capacity and low load factors. Finally, in the case of finance, McCawley (1978) said that there has been a shortage of finance especially for capital works.

Currently the number of villages is about 72,994 villages, and it is possible that the number of village will tend to increase after the government announced to allocate more fund for villages. This implies that increasing the number of rural areas without substantial efforts to provide electricity can reduce the rural electrification ratio. We need to be aware of the complexity in promoting rural electrification. The interactions of economic, social, technical and political dimension have been argued as affecting the success of the program. However, the government needs to learn from past experiences and to improve the effectiveness of rural electricity program.

\section{Method}

This study emphasizes on qualitative analysis. We compare rural electrification program that have been implemented by the PLN and Ministry of Energy and Mineral Resources (MEMR), although there are many non-government organizations (NGOs) and private companies that have been concerned to improve rural electrification ratio. One of the NGOs that has long history in facilitating energy access is IBEKA (Inisiatif Bisnis dan Ekonomi Kerakyatan), translated as People Center Business and Economic Initiative. IBEKA was established in 1992 and it focuses on micro hydro, training program, pico hydro ${ }^{2}$, biogas, and clean water supply. Then, one of the private companies that has been interested to promote mini grid is CV. Cihanjuang Inti Teknik. The company was established formally in August 2005 with specialty in microhydro and turbine specialist. In the case study analysis, we draw on the experiences of rural electrification program from East Nusa Tenggara province for three main reasons. First, the province has the lowest electricity consumption per capita.

\footnotetext{
${ }^{2}$ Hydro power based on the size of power generating that can be produced is classified into six types as follows (IRENA 2012): (1) large-hydro (more than $100 \mathrm{MW}$ ); (2) medium-hydro (20-100 MW); (3) small hydro (1-20 MW); (4) mini-hydro (100 kW-1 MW); (5) micro hydro (5-100 kW); and (6) pico-hydro (less than $5 \mathrm{~kW}$ ).
} 
Second, the electrification ratio is the second lowest after Papua. Third, NTT has the highest number of customers for solar panel.

\section{Results and Analysis}

\subsection{Rural Electrification Program Led by PT PLN}

There are two main state agencies that aim to increase substantially the electrification ratio namely the PLN and Ministry of Energy and Mineral Resources (MEMR). To support the rural electrification program, PLN has been developing two approaches such as extending on-grid and off-grid connection. To extend the grid connection, PLN has planned to develop network infrastructure both for medium and low voltage (see Table 2). It is estimated that in 2021 about $68,449 \mathrm{kms}$ (kilometer circuit) of the middle voltage network (JTM) will be constructed and $49,571 \mathrm{kms}$ of the low voltage network (JTR) also planned to be developed. Meanwhile, traffo also need to be prepared. Table 3 indicates that to support rural electrification program, the total investment between 2012 and 2021 is expected to reach about Rp27,502 billion or US $\$ 2,750$ million. Total investment cost of rural electrification program is approximately about $4.2 \%$ of total PLN investment cost between 2012 and 2021 (without counting investment cost from independent power producer).

The total number of customers that plan to be connected by electricity between 2012 and 2021 are about 2.2 million of households and 273,932 or about $12 \%$ of targeted household will obtain a cheap and power saving (listrik murah dan hemat/LMH) program. The LMH program was launched by the government in 2012. This program aims to help poor households in obtaining access to electricity. With this program, poor households obtain free energy saving lamps and prepaid electric voucher for one month. Then, government also covers the installation fee. The government said that in 2012, about 60,702 poor households wpuld have benefited from this program (DJK ESDM 2013). If we compare with the target in 2012, it seems that the rate of success of this program is about $73 \%$. In 2013 and 2014, the program covered about 95,227 households and 71,429 house- holds respectively (DJK ESDM 2013). This indicates that government's support for this program tends to decline.

A massive solar PV program (off-grid) was declared in PLN's letter No. 1227.K/DIR/2011. There are two types of supply and utilization of solar PV such as communal PV and autonomous (mandiri) PV. This program is called SEHEN, which stands for Super Ekstra Hemat Energi (Super Extra Energy Saving). PLN has allocated about Rp7 billion to support this program. There are two types of communal PV such as PV communal-autonomous and PV communal hybrid ${ }^{3}$. Table 4 indicates the characteristic of two types of PV. In the case of autonomous SEHEN, total electricity production per year is about $26.3 \mathrm{kWh}^{4}$. The two programs aim to measure problem on electricity access, but they are different in program reach. Autonomous PV has lower capacity than the communal PV but it can reach household with longer distance from PLN's grid. Basically, we cannot claim that communal PV is better than autonomous PV, but what we need to compare is the conditions before and after electricity is obtained. However, according to the AGECC (2010), it is suggested that at basic human needs, there is a minimum threshold of electricity consumption of about $50-100 \mathrm{kWh}$ person per year. Thus, autonomous PV-SEHEN is still below the minimum threshold for basic human needs.

\subsection{Rural Electrification Program Led by Central Government}

According to the Minister of Finance regulation No. 201/PMK.07/2012 on 17 December 2012, the special allocated fund (Dana Alokasi Khusus/DAK) for rural energy in 2013 has been provided. The fund needs to be used to promote renewable energy at the local level and government allocates Rp432.5 billion or US $\$ 43.25$ million. Budget for rural energy is about $1.7 \%$ of total special allocated fund. To follow this regulation up, the Minister of Energy and Mineral Resources issued regulation No. 3/2013 that consist of technical guide. The regulation said

\footnotetext{
${ }^{3}$ Communal autonomous is communal PV that is operated by individual; communal hybrid PV is communal PV that in terms of operation is combined with non-solar energy in order to improve the efficiency level.

${ }^{4}$ It is calculated from: 12 watt $\times 6$ hours $\times 365$ days.
} 
Table 2: Summary of Rural Electrification Program in Indonesia 2012-2021

\begin{tabular}{|c|c|c|c|c|c|c|}
\hline \multirow[t]{2}{*}{ Year } & \multirow[t]{2}{*}{ JTM (kms) } & \multirow[t]{2}{*}{ JTR (kms) } & \multicolumn{2}{|c|}{ Trafo } & \multirow{2}{*}{$\begin{array}{r}\text { Number of Customer } \\
(\mathrm{HH})\end{array}$} & \multirow{2}{*}{$\begin{array}{r}\text { Number of LMH } \\
(\mathrm{HH})\end{array}$} \\
\hline & & & MVA & Unit & & \\
\hline 2012 & 4,168 & 4,465 & 226 & 3,349 & 236,788 & 83,478 \\
\hline 2013 & 6,345 & 4,736 & 398 & 3,446 & 220,170 & 95,227 \\
\hline 2014 & 6,659 & 5,373 & 545 & 3,848 & 243,957 & 95,227 \\
\hline 2015 & 6,863 & 4,964 & 632 & 3,576 & 223,404 & 0 \\
\hline 2016 & 7,177 & 5,056 & 690 & 3,611 & 228,000 & 0 \\
\hline 2017 & 7,417 & 5,112 & 729 & 3,635 & 230,493 & 0 \\
\hline 2018 & 7,340 & 5,080 & 762 & 3,563 & 227,966 & 0 \\
\hline 2019 & 7,532 & 5,143 & 807 & 3,524 & 230,679 & 0 \\
\hline 2020 & 7,644 & 5,161 & 851 & 3,444 & 226,182 & 0 \\
\hline 2021 & 7,303 & 4,481 & 882 & 2,979 & 170,617 & 0 \\
\hline Total & 68,499 & 49,571 & 6,522 & 34,973 & $2,238,257$ & 273,932 \\
\hline
\end{tabular}

Source: PT PLN's business plan 2012-2021 (PT PLN 2012b)

Note: JTM = middle voltage network $20 \mathrm{kv}$;

JTR = low voltage network $220 \mathrm{v}$;

Jumlah Pelanggan PLN = number of PT PLN's customer,

Listrik Murah \& Hemat $=$ Cheap and power saving;

${ }^{\star}$ DIPA $=$ national budget.

Table 3: Summary of Investment Fund Requirement to Support the Rural Electrification Program in Indonesia 2012-2021 (Million Rp)

\begin{tabular}{rrrrrr}
\hline Year & JTM & JTR & Trafo & Lisdes Reguler & Cheap Electricity \\
\hline 2012 & $1,242,285$ & 636,569 & 381,346 & $2,260,199$ & 288,000 \\
2013 & $1,514,989$ & 769,606 & 418,384 & $2,702,976$ & 200,010 \\
2014 & $1,598,368$ & 833,676 & 437,955 & $2,870,000$ & 200,010 \\
2015 & $1,514,129$ & 776,319 & 409,553 & $2,700,000$ & - \\
2016 & $1,501,356$ & 788,920 & 409,724 & $2,700,000$ & - \\
2017 & $1,497,996$ & 793,068 & 408,936 & $2,700,000$ & - \\
2018 & $1,479,102$ & 806,870 & 414,028 & $2,700,000$ & - \\
2019 & $1,462,869$ & 821,825 & 415,306 & $2,700,000$ & - \\
2020 & $1,446,037$ & 835,161 & 418,802 & $2,700,000$ & - \\
2021 & $1,420,269$ & 589,389 & 420,342 & $2,700,000$ & - \\
\hline Total & $14,677,400$ & $7,921,403$ & $4,134,372$ & $26,733,175$ & 680,020 \\
\hline
\end{tabular}

Source: PT PLN's business plan 2012-2021 (PT PLN 2012b)

Note: JTM = middle voltage network $20 \mathrm{kv}$;

JTR = low voltage network $220 \mathrm{v}$;

Lisdes reguler $=$ reguler of rural electicity supply;

Listrik Murah \& Hemat = Cheap and power saving;

Total Biaya $=$ total cost. 
Table 4: Communal PV and Autonomous PV

\begin{tabular}{|c|c|c|c|}
\hline & Communal PV & & Autonomous PV \\
\hline 1. & $\begin{array}{l}\text { Connected capacity Location is more than } 5 \mathrm{~km} \text { of PLN's } \\
\text { grid }\end{array}$ & 1. & $\begin{array}{l}\text { Location is more than } 10 \mathrm{~km} \text { of PLN's grid or it is isolated } \\
\text { due to sea, river chasm }\end{array}$ \\
\hline 2. & Population density relatively high & 2. & $\begin{array}{l}\text { The location needs to be close between on customer and } \\
\text { other }\end{array}$ \\
\hline 3. & Customer has income to pay the electricity bill & 3. & Customer has income to pay the electricity bill \\
\hline 4. & Total capacity is 220 VA & 4. & $\begin{array}{l}\text { The capacity is only enough for } 3 \text { LED with total capacity } \\
\text { about } 3 \text { watt }\end{array}$ \\
\hline 5. & PLN finances the program & 5. & Total capacity is 12 watt \\
\hline 6. & Managed and supervised by PLN & 6. & Technical life span is 15 years for solar PV \\
\hline 7. & $\begin{array}{l}\text { The property belongs to PLN (except electricity equip- } \\
\text { ments after the energy limiter) }\end{array}$ & 7. & Technical life span is 10 years for LED \\
\hline 8. & $\begin{array}{l}\text { Tariff for autonomous communal is Rp } 14,800 \text { per month } \\
\text { (plus connection fee). This follows the Presidential Regu- } \\
\text { lation No. } 8 / 2011 \text { (for } S 1 \text { category) }\end{array}$ & 8. & LED belongs to PLN \\
\hline \multirow[t]{5}{*}{9.} & $\begin{array}{l}\text { Tariff for communal hybrid PV follows the Presidential } \\
\text { Regulation No. } 8 / 2011 \text { (plus connection fee) }\end{array}$ & 9. & PLN finances the program \\
\hline & & 10. & $\begin{array}{l}\text { This is a transition program before the customer is con- } \\
\text { nected to } 450 \mathrm{VA}\end{array}$ \\
\hline & & 11. & Managed and supervised by PLN \\
\hline & & 12. & The property belong to PLN \\
\hline & & 13. & $\begin{array}{l}\text { Total monthly payment is } \mathrm{Rp} 35,000 \text { that consists of } \\
\text { monthly fee (subscription Rp14,800 per month) and rental } \\
\text { cost of equipment Rp20,200 per month) }\end{array}$ \\
\hline
\end{tabular}

Source: PLN's Letter No. 1227.K/DIR/2011

Table 5: Type of Renewables Following the Regulation of MEMR No. 3/2013

\begin{tabular}{|c|c|c|}
\hline No & Type & Note \\
\hline 1 & Micro hydro & Small scale with capacity below $1 \mathrm{MW}$ \\
\hline 2 & Solar-concentrated & $\begin{array}{l}\text { Using photovoltaic technology, electricity is distributed on grid to end user. The number of user in } \\
\text { one community is at least } 30 \text { members. The equipment that needs to be included such as array } \\
\text { module, solar charge controller, inverter, battery bank, module array support, distribution panel, house } \\
\text { installation, power house, security system, distribution network }\end{array}$ \\
\hline 3 & Solar-dispersed & $\begin{array}{l}\text { Using photovoltaic technology, electricity is distributed off-grid or directly to end user. The number of } \\
\text { users in community should be less than } 30 \text { members. The equipment that needs to be included such } \\
\text { as array module, battery control unit, battery, lamp and box contact, inverter (if needed), module array } \\
\text { support (if needed) }\end{array}$ \\
\hline 4 & Biogas & Main component or $40-70 \%$ of methane with carbon oxide \\
\hline
\end{tabular}

Source: Regulation of MEMR No. 3/2013 
that the fund needs to be used for developing new micro hydro (less than $1 \mathrm{MW}$ ), rehabilitating micro hydro, conducting extension and improving the electricity services from micro hydro, developing solar panel (PV) (both concentrated and dispersed $)^{5}$, and installing biogas for households.

According to the Minister of Energy and Mineral Resources regulation No. 3/2013 on the action plan in utilizing new and renewable energy, there are five stages of constructing new and renewable power generating: (i) application; (ii) evaluation; (iii) decisions; (iv) procurement; (v) hand over. Technically, head of province or district or city applies the physical activity to utilize new and renewable energy to Director General of New Energy, Renewable and Energy Conservation. There are four letters that need to be attached by governor/head of district/head of city such as proposal, feasibility study, voluntary agreement to provide land, and statement to be able to accept and manage the new installment of power plant. The Director General of New Energy, Renewable and Energy Conservation then conducts evaluation and assesses all the documents (if necessary field verification can be conducted). The director general can accept or reject the proposal. Physical procurements are conducted by the director general.

After the physical project is completed, the Director General hands over the project to governor/head of district/head of city, and the project needs to pass a commissioning test. Governor/head of district/head of city needs to set up the management of the project that can be a direct participation of community or management agency such as cooperative, non-government organization, ethnic group, and informal association. Management of physical report needs to be submitted to governor/head of district/head of city every six month to the director general.

Ministry of Energy and Mineral Resources under Directorate of General Electricity and Energy Utilization has great concern on microhydro power plant. Integrated Micro-Hydro Development and Application Program (IMIDAP) is one of the organizations supported and sponsored by govern-

\footnotetext{
${ }^{5}$ Concentrated means the power is distributed and transmitted by cable to end user while dispersed means direct use to end customers. The minimum output for concentrated module is $100 \mathrm{Wp}$ per unit while for dispersed module is about $10 \mathrm{Wp}$.
}

ment, UNDP and GEF (Global Environment Facility). IMIDAP focuses on microhydro development in Indonesia. Government and stakeholders in Indonesia have a guide for microhydro construction that was prepared by IMIDAP in 2009. This guide can help provincial and city and municipality governments to conduct assessment and evaluation on microhydro projects that will be financed by APBN (national budget) and APBD (local government budget).

In 2007, the Indonesian government launched a National Program for Community Empowerment in Rural Areas (PNPM-Rural). PNPM-Rural aims to achieve a prosperous and self-reliant rural community. The PNPM has five missions: (1) enhancing community capacity and institution; (2) institutionalizing the people participation in development system; (3) promoting effective function and role of local government; (4) increasing the quality and quantity of basic social infrastructure and community finance; and (5) expanding the network of partnership in development. In order to integrate environment and natural resources management into PNPM-Rural, the government then launched a supporting program called Green PNPM as an integrated national program in alleviating poverty in Indonesia. There are three categories of green PNPM such as conservation and rehabilitation, income-generating activity, and renewable energy. In 2012, Green PNPM for renewable energy was implemented in seven provinces such as Aceh, North Sumatera, West Sumatera, Bengkulu, North Sulawesi, South Sulawesi, and Southeast Sulawesi. Basically, there are two sources of renewables such as hydro power and solar PV. The main objective of rural electrification program is to improve access to lighting especially during the night. For some regions, access to electricity can improve economic activity during the night. Furthermore, access to electricity is also necessary for safety and security reasons. The Danish Embassy as one of PNPM-MP donor, provides fund to develop a service provider database for Solar, Wind, and Biomass Energy. The directory can help stakeholder to choose the suitable technology for renewable energy.

If we compare the rural electrification program between PLN (SEHEN program) and MEMR (SHS program), there are four main differences. First, in terms of budget allocation, there is a huge difference between the two programs; for instance, PLN 
has allocated about Rp7 billion, while the government allocated more than Rp430 billion. Second, $\mathrm{PLN}$ is responsible for maintenance and operation of SEHEN, while under the SHS program maintenance and operation is under responsibility of user or community. Third, there is a monthly payment for SEHEN and payment can be made directly to the bank or to PLN's local offices. In contrast, SHS program is free of charge. If there is a payment, the amount of payment needs to be agreed by the users (bottom-up approach) and it is cheaper than SEHEN's tariff 6 . Fourth, in terms of technical specification there are differences; SHS has higher voltage than the SEHEN program.

\subsection{Lessons Learned from NTT Province}

The previous section indicates that PLN and MEMR have showed serious concern to promote rural electrification program. As seen from Table 6, the supply-side information indicates that installed capacity between 2009 and 2013 grew by $9 \%$ on average. However, the rate capacity increased by more than $11 \%$. Installed capacity shows the written capacity on nameplate. However, due to technical reasons, sometimes installed capacity cannot work optimally. Alternatively, the rated capacity indicates the real power that can be generated. The peak load indicates the highest load in the power system. Between 2009 and 2013, it increased about $17 \%$. Because the peak load is much higher than the rated capacity, it means that in some areas, there is a power deficit during the peak load. Thus, electricity black-out is the biggest challenge in many areas in NTT province. The growth of electricity demand has been very high and commercial sector has the highest growth. Most of electricity demand was driven by the residential sector and it was followed by commercial sector. Rapid growth in electricity consumption, indicates that government needs to generate more

\footnotetext{
${ }^{6}$ Interestingly in Timor Tengah Selatan District, NTT, according to local regulation No. 4/2007 on retribution in utilizing the local asset, there is a retribution for electricity utilization (micro hydro, PV, Hybrid). The monthly tariff is Rp15,000 that covers Rp10,000 for contribution to district government and $\mathrm{Rp5}, 000$ for maintenance cost (Rp2,500 for management fee and Rp2,500 for maintenance). The installation cost for micro hydro, PV, and hybrid is Rp150,000 respectively.
}

power supply for all economic sectors. In the case of residential sector, it can be supplied by both on-grid and off-grid system. The following section shares the experiences in the case of off-grid system.

Central and local government have allocated budget to support the rural electrification program. In 2010 and 2011, the provincial government constructed SHS of about 182 units and 194 units respectively (Distamben NTT 2011). The MEMR constructed about 1,843 units in 2008 and 3,582 units in 2009 (Distamben NTT 2011). The Ministry of Less-Developed Area (Kementerian Pembangunan Daerah Tertinggal/KPDT) in 2008 constructed 1,175 SHS (Distamben NTT 2011). Government also develops concentrated or communal $\mathrm{PV}^{7}$. Besides PV, there are 6 micro hydro projects that have been operated in NTT. The projects are financed by local government, central government (MEMR), and KPDT. The lowest capacity for micro hydro is about $15 \mathrm{~kW}$ and the highest is about 35 $\mathrm{kW}$. Furthermore, there are 16 units of biogas with source of funds from local and central government. Then, the National Program on Community Empowerment of Rural Independency (Program Nasional Pemberdayaan Masyarakat Mandiri Perdesaan/PNMP-MP) also allocates fund for rural electrification program. This is a bottom-up program from community. Between 2009 and 2011, in Timor Tengah Selatan (TTS) district, it showed that the total unit of SHS that had been constructed was about 4.657 units (Distamben NTT 2011).

On the other hand, we observed that NTT Province obtains the highest number of SEHEN customers. According to PT PLN, in March 2012, the number of SEHEN's customers was about 3.984 customers and in February 2013, the number of customers was more than 113,715 customers. Currently, total number of residential customers was about 343,144 customers (PLN 2011). NTT province has the highest the number of SEHEN's customers compare to other provinces such as Maluku and Maluku Utara that have total customers about 199 customers (up to April 2013). In February 2013, the total sale from SEHEN reached about Rp1.68 billion. However, the amount of ac-

\footnotetext{
${ }^{7}$ For example in 2011 MEMR developed $8 \mathrm{Kwh}$ for 40 households in sub district Pantar Timur, Alor, NTT; KPDT constructed $5 \mathrm{Kwh}$ for 30 household in Sub district Pantar, Alor, NTT, in 2010 (Distamben NTT 2011).
} 
Table 6: Supply and Demand Side of Electricity Sector in NTT

\begin{tabular}{lrrr}
\hline & 2009 & 2013 & $\begin{array}{r}\text { Average Annual } \\
\text { Growth 2009-13 } \\
(\%)\end{array}$ \\
& & & \\
\hline Supply Side (MW) & & & 9.1 \\
Installed capacity & 112.1 & 153 & 11.5 \\
Rated capacity & 73.4 & 107.3 & 17 \\
Peak load & 85.1 & 143 & \\
\hline Demand Side (GWh) & & & 16.7 \\
Residential & 223.8 & 373.4 & 16.1 \\
Industry & 4.3 & 7.1 & 22.9 \\
Commercial & 99.8 & 191 & 9.8 \\
Social & 19.1 & 26.6 & 6.9 \\
Government offices & 19.5 & 24.9 & 0.6 \\
Public light & 16.2 & 16.6 & \\
Source: PT PLN (2013) and PT PLN (2009) &
\end{tabular}

Source: PT PLN (2013) and PT PLN (2009)

Table 7: Recapitulation of SEHEN Customers (Autonomous)

\begin{tabular}{|c|c|c|c|c|c|c|c|}
\hline Month & Year & $\begin{array}{l}\text { Number of } \\
\text { Customer }\end{array}$ & Sale (Rp.) & $\begin{array}{r}\text { Account } \\
\text { Receivable (Rp.) }\end{array}$ & $\begin{array}{r}\text { Growth the } \\
\text { Number of } \\
\text { Customer (\%) }\end{array}$ & $\begin{array}{r}\text { Growth of } \\
\text { Sale (\%) }\end{array}$ & $\begin{array}{r}\text { Growth of } \\
\text { Account } \\
\text { Receivable (\%) }\end{array}$ \\
\hline April & 2012 & 6,002 & $88,829,600$ & $11,235,000$ & 50.7 & -2.0 & 30.5 \\
\hline Mei & 2012 & 13,493 & $199,683,200$ & $28,980,000$ & 124.8 & 124.8 & 157.9 \\
\hline June & 2012 & 27,287 & $403,832,800$ & $87,675,000$ & 102.2 & 102.2 & 202.5 \\
\hline September & 2012 & 50,125 & $741,850,000$ & $415,065,000$ & 15.3 & 15.3 & 25.1 \\
\hline October & 2012 & 59,030 & $873,644,004$ & $535,780,000$ & 17.8 & 17.8 & 29.1 \\
\hline November & 2012 & 68,753 & $1,017,559,200$ & $738,360,000$ & 16.5 & 16.5 & 37.8 \\
\hline December & 2012 & 97,052 & $1,436,369,600$ & $1,144,961,000$ & 41.2 & 41.2 & 55.1 \\
\hline January & 2013 & 103,743 & $1,535,278,000$ & $1,608,180,000$ & 6.9 & 6.9 & 40.5 \\
\hline
\end{tabular}

Source: PT PLN (2012a; 2012b) 
count receivable was higher than total sales. This indicates that many customers do not pay the monthly payment or PLN has not collected the monthly payment effectively.

There are three main reasons why the amount of account receivable for SEHEN has increased. First, PLN has difficulty to identify the customers that have connected to SEHEN. This is because SEHEN's customers are obtained by PLN's contractors (third party). Many of SEHEN's customers are located in remote areas and they are very difficult to reach. Thus PLN needs time to do verification and validation of SEHEN customers before PLN collects the rental payment. Second, customers refuse to pay monthly payment for several reasons: (i) distance to PLN office or local bank is too far; (ii) malfunction of SEHEN equipment; and (iii) lack of income.

In order to reduce the amount of debt, PLN has attempted to take forceble the SEHEN equipment. For example, in Timor Tengah Selatan (TTS) district, about $11 \%$ of SEHEN equipment was taking forceble. This is a hard decision, because it can reduce electrification ratio, but if PLN does not conduct this decision, PLN will have more debts. There is an idea to treat SEHEN as a charity program, but some PLN's staffs have argued that this decision will not effectively educate society. We also find that a high debt on SEHEN is also due to the SHS program. As we have indicated from the previous section, both programs are quite similar, and people tend to treat the program equally. The two programs are competing with each other. Because SHS is free of charge, people also assume that SEHEN could be free of charge. Thus, people think why we have to pay for SEHEN while others can obtain SHS for free. Even SHS is much better than SEHEN because it has higher voltage capacity than SEHEN. However, people do not consider that the payment on SEHEN aims to cover the cost of equipment and maintenance fee that needs to be done by PLN.

We also find that local government has mentioned six major problems in the implementation of SHS. First, the specification of equipment cannot meet the required contract agreement. Second, there is a change on equipment specification while the project is still ongoing. Third, lack in capacity knowledge and understanding in constructing the project. Fourth, the prepared documents are only for formality, the implementation is completely different with the planned specification. This implies that the quality of SHS program is not as good as expected. Further, there is still unclear mechanism of how the SHS users can make a claim if the SHS's equipment is broken.

Furthermore, we also observe that although local government has two options between constructing SHS and communal PV, it seems that local governments prefer to select SHS. In terms of installed capacity, the concentrated or communal PV is higher than SHS. Thus, communal PV can have higher multiplier effect in terms of stimulating productivity than SHS. However, SHS is technically easier to construct and SHS does not need local organization to manage the program. However, due to lack of transparency and accountability during the procurement process, many government officials have been jailed due to corruption on SHS program. Then, due to lack in competition, it is possible that the parties conduct cheating. For example, on 19 August 2009, the Monitoring Committee of Business Competition (Komisi Pengawas Persaingan Usaha) declared that two of the companies had conducted collusion.

\section{Conclusion and Recommen- dation}

\subsection{Conclusion}

Increasing electrification ratio especially at rural area has been addressed by the rural electrification ratio program. In the beginning, the program was started by developing small diesel power plant, but now the role of renewable energy especially micro hydro and solar panel has been promoted. However, while increasing the ratio of rural electrification ratio, government also needs to consider sufficiency, affordability and reliability of power supply. Thus, electricity use can be expanded from basic use to more productive used.

There are two major agencies namely PLN and MEMR, that are responsible to promote rural electrification program. PLN has promoted the SEHEN program, while MEMR has SHS program. The two programs are based on solar panel and it attempts to reach households that are far away from PLN's 
grid. However, the two programs are different in terms of technical, administrative, and financial aspect. Comparing the implementation between SEHEN and SHS in NTT provinces, there are four major findings. First, the number of SEHEN's customers have increased by more than 113 thousand households. This is a rapid increase in the number of PLN's customers in a very short period. As result, the number of rural and electrification ratio can be improved. However, the voltage capacity of SEHEN is very low, and it is still below the standard of basic human needs. Second, SEHEN is managed by a single authority (PLN) that is responsible for the maintenance and handling of technical problems. As the consequence, customers need to pay monthly fee. Third, head of local government is responsible for SHS program. However, local government does not have technical capacity to monitor the program, even there is a lack of technicians to conduct monitoring and evaluation. SHS's recipients are responsible for any technical problems. Fourth, there is a lack of coordination between MEMR and PLN to synchronize technical, administrative, and financial dimensions. As a result, the program seems to be competing with each other.

\subsection{Recommendation}

The study on rural electrification program has been conducted more than four decades ago, but it seems that the government lacks to acknowledge failures from the past experiences. Although the SEHEN and SHS programs have been believed to be able to promote rural electrification ratio, the government does not have a road map and strategies of how to run the program in a more systematic and effective ways. Without any improvements in designing the program, we argue that the existing program is not sustainable.

It is important to ask for contribution fee both for SEHEN and SHS. This can help both PLN and the government for better services and it is good to educate people. We observed that SEHEN and SHS can reduce kerosene consumption. Contribution fee can be designed based on the minimum quantity of kerosene that can be reduced after using SEHEN or SHS. Thus, in NTT, SEHEN and SHS can reduce government subsidy on kerosene. While in Java and other provinces government has conver- sion program from kerosene to $3 \mathrm{~kg}$ LPG (liquid petroleum gas), in NTT government can implement conversion program from kerosene to electricity.

From the technical dimension, we argue that SEHEN has higher degree of sustainability than other programs because PLN guarantees for maintenance services. Government needs to support the program by providing subsidy for the poor. It is necessary to prepare a new organization within PLN that will be responsible to organize and manage rural electrification program. Because PLN has capacity knowledge and experiences, PLN needs to be pointed as the focal point to execute and implement the rural electrification program. However, due to lack of human resource at the front-line level, it is necessary to add new staffs to manage this program.

\section{References}

[1] AGECC 2010, 'Energy for A Sustainable Future', Summary report and recommendations, The SecretaryGeneral's Advisory Group on Energy and Climate Change (AGECC), New York.

[2] Distamben NTT 2011, Data Potensi dan Pengembangan Energi Baru Terbarukan, Dinas Pertambangan dan Energi Provinsi Nusa Tenggara Timur, Kupang.

[3] DJK ESDM 2013, Program Listrik Hemat dan Murah dalam Pameran Musrembangnas 2013, Direktorat Jenderal Ketenagalistrikan, Kementerian Energi dan Sumber Daya Mineral. Available from: $<$ http://portal.djlpe.esdm.go.id/modules/news/ ?_act=detail\&sub=news_media\&news_id=3532>. [20 August 2014].

[4] IRENA 2012, Renewable Energy Technologies: Cost Analysis Series, vol. 1 (Power Sector), issue 3/5: Hydropower. International Renewable Energy Agency, Germany. Available from: <http: //www.irena.org/DocumentDownloads/Publications / RE_Technologies_Cost_Analys is - HYDROPOWER.pdf $>$. [21 August 2014]

[5] Kanagawa, M \& Nakata, T 2008, 'Assessment of Access to Electricity and the Socio-economic Impacts in Rural Areas of Developing Countries', Energy Policy, vol. 36, no. 6, 2016-2029.

[6] McCawley, P 1978, 'Rural Electrification in Indonesia-Is It Time?', Bulletin of Indonesian Economic Studies, vol. 14, no. 2, 34-69.

[7] Mohsin, A 2014, 'Wiring the New Order: Indonesian Village Electrification and Patrimonial Technopolitics (19661998)', SOJOURN: Journal of Social Issues in Southeast Asia, vol. 29, no. 1, 63-95.

[8] Munasinghe, M 1988, 'Rural Electrifiction: International Experience and Policy in Indonesia', Bulletin of Indonesian Economic Studies, vol. 24, no. 2, 87-105.

[9] PT PLN 2009, Statistik PLN 2009, PT PLN (Persero), Jakarta. 
[10] PT PLN 2011, Statistik PLN 2011, PT PLN (Persero), Jakarta.

[11] PT PLN 2012a, Statistik PLN 2012, PT PLN (Persero), Jakarta.

[12] PT PLN 2012b, Rencana Usaha Penyediaan Tenaga Listrik PT. PLN (Persero) 2012-2021, PT PLN (Persero), Jakarta.

[13] Winkler, H, Simoes, AF, Rovere, EL, Alam, M, Rahman, A, \& Mwakasonda, S 2011, 'Access and Affordability of Electricity in Developing Countries'. World Development, vol. 39 , no. $6,1037-1050$ 